Joanna Zalewska* (iD http://orcid.org/0000-0003-2240-4308

Akademia Pedagogiki Specjalnej im. Marii Grzegorzewskiej w Warszawie

https://doi.org/10.25312/2083-2923.18/2020_04jz

\title{
Strategie preferowane przez „małych nauczycieli" w trakcie uczenia „małych uczniów" rozwiązywania zadań matematycznych z treścią. Sprawozdanie z badań
}

\begin{abstract}
Streszczenie: Charakterystyczną cechą uczenia się matematyki jest rozwiązywanie specjalnie dobranych zadań. W trakcie układania i rozwiązywania zadań dzieci gromadzą doświadczenia matematyczne i logiczne. $\mathrm{Z}$ tych doświadczeń ich umysł konstruuje wiadomości i umiejętności matematyczne. Szczególną rolę pełnią zadania z treścią, gdyż w trakcie ich rozwiązywania uczniowie dodatkowo uczą się stosować posiadane już wiadomości i umiejętności w sytuacjach życiowych.

Kluczową kwestią dla potrzeb edukacji matematycznej jest badanie sposobów rozumowania dzieci w młodszym wieku szkolnym w trakcie rozwiązywania zadań matematycznych. $\mathrm{W}$ artykule omawiam strategie preferowane przez uczniów klas trzecich w sytuacji, kiedy uczą ucznia klasy pierwszej rozwiązywać zadanie matematyczne z treścią. Przedstawiam też fragmenty szczegółowej analizy empirycznej zachowań werbalnych i niewerbalnych uczniów pracujących w parach nad rozwiązaniem specjalnie dobranych zadań.
\end{abstract}

Słowa kluczowe: proces uczenia się dzieci w młodszym wieku szkolnym, rozwiązywanie zadań matematycznych, tutoring uczniowski

\footnotetext{
Joanna Zalewska - magister pedagogiki, specjalność wczesnoszkolna, pracownik Akademii Pedagogiki Specjalnej im. Marii Grzegorzewskiej w Warszawie, nauczyciel dyplomowany z wieloletnim stażem pedagogicznym. Obszar zainteresowań: edukacja matematyczna, specyfika dziecięcego rozumowania, innowacyjne metody nauczania.
} 
Rzecza dla człowieka najważniejsza jest wychowanie.

Albowiem każda rzecz dobrze rozpoczęta daje nadzieję dobrego wyniku.

Antyfon Sofista

Misją edukacji, od czasu sformułowania jej przez starożytnych Greków pod nazwą paidea $^{1}$, było i jest nadal wykształcenie młodego człowieka i przygotowanie go do życia w społeczeństwie. Inaczej człowiek nie będzie w stanie nadążyć za tempem zmian i nie nabędzie należytych nawyków selektywnego korzystania z wiedzy napływającej z różnych źródeł, co może skutkować „zatonięciem w powodzi informacji”2.

Dlatego też bezspornie problemem kluczowym dla potrzeb edukacji XXI wieku jest właściwe planowanie działalności pedagogicznej ukierunkowanej na wspieranie aktywności dziecka przez organizowanie sytuacji edukacyjnych umożliwiających eksperymentowanie i nabywanie doświadczeń oraz rozwijanie takich umiejętności, jak: kreatywność, innowacyjność i samodzielność3. W kontekście tych oczekiwań konieczne jest, aby uczniowie już od pierwszej klasy szkoły podstawowej rozwijali swoje kompetencje matematyczne poprzez rozwiązywanie specjalnie dobranych zadań.

\section{Wieloznaczność pojęcia zadanie}

Zadanie jest pojęciem niejednoznacznym. W Ilustrowanym słowniku języka polskiego ${ }^{4}$ jest ono określone jako cel, misja do wypełnienia, posłannictwo, obowiązek, zagadnienie matematyczne, fizyczne itp. wymagające rozwiązania. Potocznie przez zadanie

${ }^{1}$ Wielkie zasługi Arystotelesa w zakresie pedagogiki polegały na ustaleniu procesu dydaktycznego pod względem psychologicznym i logicznym. Celem paidei - tak pojętej roli edukacji - było ukształtowanie, wyedukowanie człowieka pięknego i mądrego w oparciu o najwyższe ideały i najdoskonalsze wzorce, zaś jej podstawowym składnikiem były kwestie związane ze szlachetnością, moralnością czy dobrocią człowieka. Zob. M. Kocur, Arystotelesowskie poglądy konstytutywną częścia filozofii i pedagogiki, [w:] A. Murzyn (red.), Paideia starożytnej Grecji i Rzymu, Oficyna Wydawnicza „Impuls”, Kraków 2011, s. 11-21.

${ }^{2}$ Zob. Z. Bauman, Wyzwania dla edukacji w dobie płynnej nowoczesności, [w:] R. Siemieńska (red.), Uniwersytety, naukowcy i studenci w zglobalizowanym świecie: wybrane zagadnienia, Wydawnictwo Naukowe Scholar, Warszawa 2017, s. 15-29.

3 Zob. Podstawa programowa kształcenia ogólnego dla szkoły podstawowej, I i II etap edukacyjny, stanowiąca załącznik nr 2 do Rozporządzenia Ministra Edukacji Narodowej z dnia 14 lutego 2017 r. w sprawie podstawy programowej wychowania przedszkolnego oraz podstawy programowej kształcenia ogólnego dla szkoły podstawowej, w tym dla uczniów z niepełnosprawnością intelektualną w stopniu umiarkowanym lub znacznym, kształcenia ogólnego dla branżowej szkoły I stopnia, kształcenia ogólnego dla szkoły specjalnej przysposabiającej do pracy oraz kształcenia ogólnego dla szkoły policealnej, Dz.U. 2017, poz. 356, s. 16.

${ }^{4}$ E. Sobol (red.), Ilustrowany słownik języka polskiego, PWN, Warszawa 1999, s. 1081. 
rozumie się sytuację zadaniową, którą należy rozwiązać, i dotyczy to głównie rozwiązywania zadań na lekcjach matematyki ${ }^{5}$. W ujęciu psychologicznym zadanie jest traktowane jako mniej lub bardziej sprecyzowany cel, do którego się dąży podczas jego wykonywania ${ }^{6}$. W momencie przezwyciężania trudności - kiedy uczeń nie może rozwiązać zadania od razu i wprost za pomocą posiadanego zasobu wiedzy - zadanie określa się mianem problemu. Natomiast nie każde zadanie jest problemem dla ucznia. To samo zadanie może być problemem dla jednego ucznia, a dla drugiego już nie. Decydują o tym indywidualne doświadczenie oraz konkretne kompetencje ${ }^{7}$. Problem traktowany jest zatem jako rodzaj zadania, które wymaga od uczniów myślenia o charakterze produktywnym. Problem jest sytuacją trudną, niepewną, nową, ale nie każda trudność, niepewność czy nowość może stanowić problem. Rozwiązywać zadanie o charakterze problemowym znaczy pokonywać trudności oraz przeszkody zarówno myślowe, jak i praktyczne, które uniemożliwiają osiągnięcie tego celu.

Badania $^{8}$ wykazują, że wykorzystywanie maksymalnie możliwości rozwojowych dzieci zależy od stadium rozwojowego uczącego się dziecka, jak również od rodzaju stawianych mu zadań, bo uczeń tworzy sobie taką koncepcję matematyki, jaka mu się

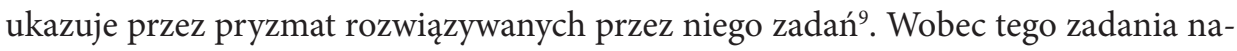
leży dobierać tak, aby stanowiły dla uczniów pewną niejasność, trudność, z którymi będzie musiał się zmierzyć, włożyć w rozwiązanie wysiłek intelektualny.

W opinii uznanego dydaktyka matematyki ${ }^{10}$ już samo pojęcie trudności zadania określa jego właściwość. Tam, gdzie nie ma żadnej przeszkody, a sposób na zaspokojenie potrzeby rodzi się od razu w mózgu, nie ma też zadania. Zadanie pojawia się wówczas, kiedy nie od razu znajdujemy sposób na jego rozwiązanie, ale zachodzi konieczność świadomego poszukiwania środka, za pomocą którego można osiągnąć dobrze widoczny, lecz chwilowo niedostępny cel. Znalezienie tego środka jest równoznaczne $\mathrm{z}$ rozwiązaniem zadania.

Zadania, które rozwiązuje się bez trudu, czyli łatwo znajduje się ten środek, nazywa się w matematyce zadaniami małymi, błahymi ${ }^{11}$. Rozwiązanie tego typu zadań

${ }^{5}$ Przeważającej większości moich studentów matematyka kojarzy się wyłącznie z pracą na lekcji, ze sprawdzianami i kartkówkami oraz z mozolną pracą i z uczeniem się na pamięć wzorów i definicji oraz rozwiązywaniem zadań według jednego schematu, algorytmu itp.

${ }^{6}$ M. Tyszkowa, Zachowanie się dzieci 5-12 letnich $w$ trudnych sytuacjach zadaniowych, [w:] J. Obuchowska, O.W. Owczynnikowa, J. Reykowski (red.), Badania nad osobowością dzieci i młodzieży, WSiP, Warszawa 1979, s. 122.

7 Por. J. Kozielecki, Rozwiązywanie problemów, Państwowe Zakłady Wydawnictw Szkolnych, Warszawa 1969, s. 14-16; D. Klus-Stańska, M. Nowicka, Sensy i bezsensy edukacji wczesnoszkolnej, Harmonia Universalis, Gdańsk 2014, s. 181.

${ }^{8}$ Z. Włodarski, Rozwój i kształtowanie doświadczenia indywidualnego, PWN, Warszawa 1975, s. 16.

9 Z. Krygowska, Zarys dydaktyki matematyki. Cz. 3, WSiP, Warszawa 1980, s. 3.

${ }^{10}$ G. Polya, Odkrycie matematyczne. O rozumieniu, uczeniu się i nauczania rozwiązywania zadań, cz. 1 i 2, Wydawnictwa Naukowo-Techniczne, Warszawa 1975, s. 145.

${ }_{11}$ Tamże, s. 145. 
ćwiczy przede wszystkim wykonywanie typowych operacji i uczy stosowania wyuczonych algorytmów. Do zadań prostych zalicza się ćwiczenia rachunkowe służące korzystaniu z wiedzy już nabytej i rozwijaniu sprawnych metod obliczeń.

Natomiast zadania-problemy stanowią pewną przeszkodę, niepewność, a ich rozwiązanie wymaga nieraz kreatywnego i oryginalnego poszukiwania dróg pokonania trudności. W sytuacji zadania-problemu występuje jedna lub kilka trudności. Odczucie tych trudności skłania uczniów do formułowania hipotez i poszukiwania rozwiązań, a ich przezwyciężanie prowadzi do nabywania nowych doświadczeń.

$\mathrm{Z}$ uwagi na to, iż podstawową działalnością uczniów na lekcjach matematyki jest rozwiązywanie zadań, charakterystyczną cechą edukacji matematycznej jest nabywanie doświadczeń logicznych i matematycznych, warto rozwiązywać takie zadania, których rozwiązanie wymaga samodzielności i kreatywności w poszukiwaniu dróg pokonania trudności. Takimi zadaniami wydają się zadania problemowe, tak zwane zadania wielkie ${ }^{12}$.

W kontekście nauczania - uczenia się matematyki w klasach młodszych - rozwiązywanie zadań z treścią jest tym rodzajem czynności, które najbardziej absorbują ucznia i wyzwalają ciekawość, odwołując się do jego wyobraźni i naturalnych zamiłowań do badań doświadczalnych ${ }^{13}$. W toku rozwiązywania cudzych lub własnych problemów, mierząc się z zadaniem, uczeń przyswaja metody postępowania ${ }^{14}$. Natomiast inne umiejętności rozwijane w klasach początkowych mają charakter usługowy w stosunku do rozwiązywania zadań i są one narzędziami potrzebnymi do skutecznego radzenia sobie z matematycznymi zadaniami z treścią ${ }^{15}$.

\section{Zadania z treścią w początkowej edukacji matematycznej}

Zadania z treścią są układane i rozwiązywane, bo są podstawą kształcenia myślenia matematycznego i uczą zastosowań nabytych wiadomości i umiejętności w życiu codziennym ${ }^{16}$. Zdaniem wielu dydaktyków matematyki i pedagogów zadania $\mathrm{z}$ treścią

12 Tamże, s. 145.

${ }^{13}$ J. Dewey w książce Jak myślimy?, Książka i Wiedza, Toruń 1957, s. 11, pisze, że „dziecko niezepsute przez wychowanie cechuje paląca ciekawość, płodna wyobraźnia i zamiłowanie do badań doświadczalnych".

${ }^{14}$ E. Gruszczyk-Kolczyńska, Wspomaganie rozwoju umysłowego oraz edukacja matematyczna dzieci w ostatnim roku wychowania przedszkolnego i w pierwszym roku szkolnej edukacji, Edukacja Polska, Warszawa 2009, s. 21.

${ }^{15}$ M. Dąbrowski, (Za) trudne, bo trzeba myśleć?, Instytut Badań Edukacyjnych, Warszawa 2013, s. 8 .

${ }^{16}$ E. Gruszczyk-Kolczyńska, Dojrzałość emocjonalna i jej znaczenie w uczeniu się matematy$k i$, [w:] E. Gruszczyk-Kolczyńska, Dzieci ze specyficznymi trudnościami w uczeniu się matematyki. Przyczyny, diagnoza, zajęcia korekcyjno-wyrównawcze, WSiP, Warszawa 1992, s. 138-152. 
stanowią punkt wyjścia do wprowadzania nowych pojęć, służą utrwaleniu i pogłębieniu rozumienia pojęć już poznanych ${ }^{17}$.

Zadania z treścią są rodzajem sytuacji problemowej i mogą mieć charakter praktyczny lub teoretyczny. Są opisem sytuacji życiowej lub historyjki, w której pewne liczby lub wielkości są dane, a pewne inne liczby lub wielkości należy obliczyć, wykorzystując związki pomiędzy nimi wynikające z treści zadania ${ }^{18}$. W odróżnieniu od innych typów edukacji (np. polonistycznej, przyrodniczej, artystycznej) edukacja matematyczna posługuje się własnym, specyficznym i jednoznacznym językiem. Jest to głównie język symboli. Dlatego też zadania z treścią są formułowane w specyficznym stylu: część w języku potocznym, a część w konwencji języka matematycznego ${ }^{19}$. Na rozwiązanie takiego zadania składa się szereg czynności poznawczych. Dziecko, rozwiązując zadanie, ma zrozumieć sens historyjki przedstawionej w specyficznej konwencji szkolnego zadania tekstowego, czyli zrozumieć matematyczną strukturę zadania. Na początku dziecko musi zapoznać się z zadaniem, dokonać analizy treści, wyłuskać dane i szukane, uświadomić sobie, jakie są zależności pomiędzy nimi, a także czego dotyczy pytanie końcowe. Następnie musi to wszystko przełożyć na język matematyki, czyli dokonać matematyzacji sytuacji życiowej przedstawionej w zadaniu ${ }^{20}$.

Tymczasem, jak pokazują badania E. Gruszczyk-Kolczyńskiejej z lat dziewięćdziesiątych i kolejne raporty $\mathrm{z}$ badań ${ }^{2}$, znaczna część trzecioklasistów w ogóle nie

${ }^{17}$ Zob. L. Jeleńska, Kształcenie myślenia matematycznego, [w:] L. Jeleńska, A.M. Rusiecki, Metodyka arytmetyki i geometrii w pierwszych latach nauczania, Państwowe Zakłady Wydawnictw Szkolnych, Warszawa 1958, s. 101-122; Z. Krygowska, dz. cyt., s. 6-13; E. Puchalska, Z. Semadeni, Nowe spojrzenie na zadanie tekstowe, [w:] Z. Semadeni, J. Bargoń (red.), Nauczanie początkowe matematyki. Tom 1, WSiP, Warszawa 1981, s. 41-46; E. Gruszczyk-Kolczyńska, Układanie i rozwiązywanie nieco bardziej złożonych zadań z treścia, [w:] E. Gruszczyk-Kolczyńska (red.), Edukacja matematyczna w klasie I. Książka dla rodziców i nauczycieli, Wydawnictwo CEBP, Kraków 2014, s. $145-154$.

${ }_{18}$ Z. Semadeni, E. Gruszczyk-Kolczyńska, G. Treliński, B. Bugajska-Jaszczołt, M. Czajkowska (red.), Matematyczna edukacja wczesnoszkolna. Teoria i praktyka, Wydawnictwo Pedagogiczne ZNP, Kielce 2015, s. 102.

19 E. Gruszczyk-Kolczyńska, E. Zielińska, Dziecięca matematyka dwadzieścia lat później. Książka dla rodziców i nauczycieli starszych przedszkolaków, Bliżej Przedszkola, Kraków 2015, s. 138.

${ }^{20}$ M. Dąbrowski, E. Wiatrak, Podsumowanie badania umiejętności matematycznych, [w:] A. Pregler, E. Wiatrak (red.), Ogólnopolskie Badanie Umiejętności Trzecioklasistów. Raport OBUT 2012, 2013 i kolejne, Centralna Komisja Egzaminacyjna, Warszawa, s. 6; A. Kalinowska, Umiejętności matematyczne uczniów kończących klasę trzecią. Czytanie tekstów matematycznych, [w:] M. Dąbrowski (red.), Trzecioklasiści 2010. Raport z badań ilościowych, Centralna Komisja Egzaminacyjna, Warszawa 2011, s. 324; M. Dąbrowski, (Za) trudne..., dz. cyt., s. 82-98.

${ }^{21}$ Na problem trudności nadmiernych i specyficznych zwraca uwagę E. Gruszczyk-Kolczyńska i opisuje bolączki, z jakimi mierzy się dziecko, rozwiązując zadanie tekstowe w szkole na podstawie wieloletnich badań nad zjawiskiem niepowodzeń w uczeniu się matematyki. Zob. E. Gruszczyk-Kolczyńska, Dzieci ze specyficznymi trudnościami w uczeniu się matematyki. Przyczyny, diagnoza, zajęcia korekcyjno-wyrównawcze, WSiP, Warszawa 1992, s. 71-82.

${ }_{22}$ Zob. M. Dąbrowski, O umiejętnościach matematycznych trzecioklasistów - subiektywny wybór z badań, „Studia Pedagogiczne” 2015, nr LXVII, s. 289-302 oraz A. Pregler, E. Wiatrak (red.), 
czyta treści zadania, a uczniowie, którzy przeczytają zadanie, nie próbują zrozumieć istoty zależności pomiędzy informacjami w nich podanymi. Skupiają się głównie na danych liczbowych oraz słowach kluczach, które sugerują, jakie działanie trzeba wykonać (dodawanie, odejmowanie, mnożenie, dzielenie), aby zadanie rozwiązać. Bywa często tak, że uczeń wyłuskuje dane liczbowe z zadania i tworzy z nich działanie, którego rozwiązanie nie ma logicznego związku z pytaniem końcowym.

Inną przyczyną trudności związanych z rozwiązywaniem zadań z treścią może być to, że nauczyciele preferują algorytmiczną metodę rozwiązywania zadań złożonych ${ }^{23}$. Problem w tym, że nauczyciele stosujący tę metodę mają wówczas świadomość planu rozwiązania zadania i prowadzą krok po kroku uczniów do jego rozwiązania. Uczniowie, nie znając planu rozwiązania zadania, wykonują kolejne działania ${ }^{24}$ pod dyktando nauczyciela, nie próbując nawet zrozumieć sensu wykonywanych czynności ${ }^{25}$. Niezamierzonym efektem algorytmicznej metody jest także to, że uczniowie nie uczą się tworzyć planu rozwiązywania zadania, a potem konsekwentnie go realizować. Dlatego przestają dążyć do rozwiązania zadania przy pierwszym odczuciu trudności.

Niezrozumienie sposobu rozumowania dzieci podczas rozwiązywania zadań może spowodować to, że nauczyciel zamiast kierować ich rozumowaniem, będzie próbował wyjaśniać i poda gotowy wynik rozumowania, chcąc, żeby dziecko to powtórzyło.

Przedstawione koncepcje zarówno psychologiczne, jak i matematyczne koncentrują się głównie na wykonywaniu zadania jako na rozwiązaniu problemu czy osiągnięciu celu, co zwykle jest złożonym procesem, mniej lub bardziej rozciągniętym w czasie.

Zasygnalizowany w tym artykule problem trudności z rozwiązywaniem zadań i rozbieżności pomiędzy metodami nauczycielskimi i uczniowskimi jest jedną z głównych przyczyn podjęcia badań jakościowych i poznania strategii intelektualnych stosowanych przez uczniów klas w rozwiązywaniu zadań matematycznych.

Ogólnopolskie Badanie Umiejętności Trzecioklasistów. Raport OBUT 2012, 2013 i kolejne, Centralna Komisja Egzaminacyjna, Warszawa.

${ }^{23}$ Zob. D. Klus-Stańska, Mentalne zniewolenie nauczycieli wczesnej edukacji - epizod czy prawidłowość, „Problemy Wczesnej Edukacji” 2005, nr 1(1), s. 55-66; D.A. Kalinowska, Pozwólmy dzieciom działać. Mity i fakty w kształceniu myślenia matematycznego, [w:] M. Dąbrowski (red.), Badanie umiejętności podstawowych uczniów trzecich klas szkoły podstawowej. Trzecioklasista i jego nauczyciel, Centralna Komisja Egzaminacyjna, Warszawa 2009, s. 321-327.

${ }^{24} 78,3 \%$ badanych nauczycieli twierdzi, że podstawowym zadaniem nauczyciela jest staranne tłumaczenie dzieciom, jak mają rozwiązać zadanie. Zob. A. Kalinowska, Nauczyciele o edukacji matematycznej, [w:] M. Dąbrowski (red.), Badanie umiejętności podstawowych uczniów trzecich klas szkoły podstawowej. Trzecioklasista i jego nauczyciel, Centralna Komisja Egzaminacyjna, Warszawa 2009, s. 326.

${ }^{25}$ E. Gruszczyk-Kolczyńska, Dzieci ze specyficznymi..., dz. cyt., s. 9. 


\section{Metodologia badań}

W celu poznania uczniowskich strategii stosowanych w rozwiązywaniu zadań matematycznych zastosowałam w badaniach zaproponowany przez E. Gruszczyk-Kolczyńską (promotora pracy) oryginalny sposób dotarcia do procesów intelektualnych poprzez zorganizowanie sytuacji, w których dziecko starsze uczy dziecko młodsze, jak rozwiązać zadanie. Korzystając z wcześniejszych doświadczeń badaw$\mathrm{czych}^{26}$, uznałam, że zastosuję metodę eksperymentu diagnostycznego ${ }^{27}$ typu tutoring uczniowski ${ }^{28}$, co dało szansę „wniknięcia w głąb” myślenia (ang. get inside ${ }^{29}$ ) uczniów kończących pierwszy etap edukacyjny i poznania preferowanych przez nich sposobów rozwiązywania zadań $z$ treścią.

Zastosowana przeze mnie metoda eksperymentów diagnostycznych jest utrzymana w konwencji tutoringu rówieśniczego ${ }^{30}$ i polega na organizowaniu sytuacji edukacyjnych typowych dla tutoringu. Najkrócej mówiąc:

- uczeń, który więcej wie, potrafi wykorzystać swój potencjał intelektualny i we wspierającej relacji prowadzi ucznia słabszego po ścieżkach swojego rozumowania, dążąc do tego, aby uczeń, z którym współpracuje, rozwiązał zadanie samodzielnie lub z jego pomocą,

${ }^{26}$ Z.I. Kałmykowa, Problemowo-syntetyczna metodyka diagnostyki nauczalności, [w:] L. Wołoszynowa (red.), Materiały do nauczania psychologii, seria 3, t. 2, PWN, Warszawa 1973.

${ }_{27}$ Opisując to narzędzie, E. Gruszczyk-Kolczyńska wyjaśnia, że powołuje się na ustalenia Kałmykowej. Zob. Z.I. Kałmykowa (red.), Ostajuszczije w uczenii szkolniki. Problema psychiczeskowo rozwitija, Moskwa 1986. Narzędzie to zamieszczone jest w książce E. Gruszczyk-Kolczyńska (red.), Wiadomości i umiejętności oraz zarysowujące się uzdolnienia matematyczne starszych przedszkolaków i małych uczniów. Podręcznik, narzędzia diagnostyczne oraz wskazówki do wspomagania rozwoju umysłowego i edukacji uzdolnionych dzieci, Akademia Pedagogiki Specjalnej w Warszawie, Warszawa 2010. Projekt nr 1700603 Rozpoznawanie i wspomaganie rozwoju uzdolnień do uczenia się matematyki u starszych przedszkolaków i małych uczniów, finansowany przez Ministerstwo Szkolnictwa Wyższego i Nauki ze środków na wspieranie badań naukowych w latach 2007-2010. Zrealizowany w Akademii Pedagogiki Specjalnej w Warszawie.

${ }^{28}$ O tutoringu dziecięcym (rówieśniczym, uczniowskim) możemy mówić w sytuacjach, w których dzieci mogą pomagać innym w rozwiązywaniu problemów. Zob. M. Sławińska, Tutoring rówieśniczy w edukacji, czyli jak uczniowie ucza się od siebie wzajemnie i co z tego wynika, „Forum Oświatowe" 2015, nr 27(2), s. 41-56.

${ }^{29}$ Niektóre przejawy intuicji określa się mianem insight (wgląd), który często utożsamiany jest z olśnieniem. Zob. N. Wiszniakowa-Zielenskiy, Koncepcje rozwoju kreatywnego potencjału człowieka, Oficyna Wydawnicza AFM, Kraków 2016, s. 31. Wśród mechanizmów uczenia się psycholodzy wyodrębniają uczenie się przez wgląd. Por. E. Gruszczyk-Kolczyńska, Dzieci ze specyficznymi trudnościami..., dz. cyt., s. 184; J. Piaget, Studia z psychologii dziecka, PWN, Warszawa 1966, s. 17; J. Piaget, Mowa i myślenie dziecka, PWN, Warszawa 1992.

30 Tutoring rówieśniczy występuje w sytuacji edukacyjnej, ,kiedy bardziej wprawne dzieci zaczynają udzielać instrukcji i porad innym dzieciom, by wprowadzić je na podobny do swojego poziom kompetencji”. Zob. H.R. Schaffer, Psychologia dziecka, PWN, Warszawa 2005, s. 233. 
- uczeń, który mniej umie, poddaje się prowadzeniu ucznia, który więcej potrafi, i we współpracy z nim stara się rozwiązać zadanie mniej lub bardziej samodzielnie.

Dla zrealizowania takiego zamiaru naukowego wyodrębniłam dwie grupy dzieci, które pełniły rolę „małego nauczyciela” i „małego ucznia” i połączyłam ich w dwuosobowe zespoły. Były to pary: dziewczynka-dziewczynka, dziewczynka-chłopiec, chłopiec-chłopiec, chłopiec-dziewczynka. Łącznie zorganizowałam 27 eksperymentów diagnostycznych, czyli sytuacji, w których „mały nauczyciel” uczył „małego ucznia" rozwiązywać zadanie z treścią ${ }^{31}$.

\section{Rezultaty badań}

Obserwując i analizując zachowanie uczniów biorących udział w eksperymencie ${ }^{32}$, dało się zauważyć pewne ciągi czynności, które powtarzali wszyscy „mali nauczyciele” niezależnie od sposobu prowadzenia i stymulowania „małego ucznia”. Powtarzające się sekwencje czynności intelektualnych wytyczały kierunek myślenia „małego nauczyciela" i stanowiły rozumny tok postępowania w rozwiązywaniu zadania matematycznego.

Ustaliłam, że powtarzające się ciągi aktywności nie były zależne od struktury i stopnia trudności zadania. Wszyscy, co do jednego, „mali nauczyciele” w trakcie uczenia „małego ucznia” posługiwali się głośnym myśleniem ${ }^{33}$. Głośnemu myśleniu towarzyszyła manipulacja przedmiotami ${ }^{34}$.

Wszyscy „mali nauczyciele” po zapoznaniu się z treścią zadania (czytanie ciche bądź głośne) dążyli do przekładania treści zadania podanego w formie tekstu pisanego w rodzaj problemowego wydarzenia matematycznego (scenki), w którym główną

${ }^{31}$ Analizując różne koncepcje, przyjęłam, że przez zadanie matematyczne z treścią rozumiem każdą sytuację problemową, przedstawioną ustnie lub pisemnie, której rozwiązanie wymaga pewnego wysiłku intelektualnego i zastosowania skutecznej metody, sposobu czy strategii.

${ }^{32} \mathrm{~W}$ niniejszym artykule zostały przedstawione fragmenty eksperymentów diagnostycznych, jakie przeprowadziła autorka artykułu w ramach przygotowań do rozprawy doktorskiej pt. Strategie intelektualne stosowane przez uczniów klasy trzeciej w rozwiązywaniu zadań matematycznych, pisanej pod kierunkiem prof. zw. dr hab. E. Gruszczyk-Kolczyńskiej oraz badań zrealizowanych w ramach grantu nr BSTP 16/16-I w latach 2016-2017 w Akademii Pedagogiki Specjalnej w Warszawie.

${ }^{33}$ Sformułowanie głośne myślenie nawiązuje do ustaleń L.S. Wygotskiego, ale w przypadku moich badań dotyczy rozwiązywania konkretnych zadań, czyli eksterioryzacji, kiedy dziecko badało związki pomiędzy informacjami zawartymi w zadaniu, posługując się nabytymi wiadomościami i umiejętnościami. Zob. L.S. Wygotski, Narzędzie i znak w rozwoju dziecka, Wydawnictwo Naukowe PWN, Warszawa 2006.

${ }^{34}$ Poprzez ruch, oddziaływanie na rzeczy, manipulowanie przedmiotami dziecko dostrzega zależności i dzięki temu może planować świadomie kolejne czynności: odkrywając, wymyślając lub projektując różne sposoby działania prowadzące do osiągnięcia zamierzonego celu. Zob. S. Szuman, Rola działania w rozwoju umysłowym małego dziecka, Wydawnictwo Polskiej Akademii Nauk, Wrocław 1955, s. 14-16. 
rolę odgrywały dane zawarte w zadaniu i związki pomiędzy nimi. Rozwiązanie (ang. proces-solving procedure) organizowali w następujący sposób:

- obrazowali dane zbiorami zastępczymi (wyłuskiwali istotne elementy z zadania i zastępowali je przedmiotami: klockami, sznurkami, kolorowymi szkiełkami, żetonami, ołówkami, kartkami),

- uwidaczniali (odsłaniali) relacje pomiędzy wielkościami danymi i szukanymi, manipulując zbiorami zastępczymi: przekładali, rozkładali, przesuwali elementy tych zbiorów, komentując wykonywane czynności (posunięcia).

W trakcie wykonywania tych czynności „mali nauczyciele” obserwowali zachowanie „małego ucznia” i sprawdzali, czy rozumie sens zadania, czy wie, co jest przedmiotem i celem działania. Czynili to na wiele sposobów:

- stawiali pytania konkretne, wprost odnoszące się do pytania końcowego np.: To ile musisz przełożyć z tego, (gest wskazujacy) żeby było po tyle samo? To ile trzeba przełożyć jabłek, żeby było równo tu i tu? (gest wskazujący),

- zadawali pytania po każdej wykonywanej czynności: Rozumiesz? Wszystko rozumiesz? Tak? Prawda?,

- nawiązywali kontakt wzrokowy i oczekiwali potwierdzenia w formie werbalnej lub niewerbalnej, że rozumieją, co jest dane w zadaniu i czego szukamy.

Uwieńczeniem działań podejmowanych przez „małego nauczyciela” było demonstrowane poczucie zadowolenia: Rozumie sens zadania. Informacja ta była istotnym bodźcem do podjęcia kolejnych czynności zmierzających do głębszego wniknięcia w problem i rozwiązania zadania.

W kolejnym kroku „mali nauczyciele” skupiali się na badaniu związków pomiędzy informacjami zawartymi w treści zadania. Eksperymentowali i rozważali różne warianty: przekładania, przesuwania, rozkładania, przeliczania itd. zbiorów zastępczych wraz z komentarzem werbalnym bądź niewerbalnym. W trakcie wykonywania tych czynności „mali nauczyciele” monitorowali i sprawdzali sens eksperymentowania przedmiotami o charakterze kombinatorycznym. W razie potrzeby dokonywali stosownych korekt, na przykład:

- manipulowali przedmiotami i pytali: Wszystko rozumiesz? Widzisz? Wiesz już? To ile tu jest? To ile musisz przełożyć? Więc, co jest pierwsze? Który z pojazdów jedzie pierwszy?,

- instruowali (kierowali działaniem „małego ucznia”) i mówili: Przełóż! Przesuń! Policz! Zmierz! Wystarczy tylko poprzekładać.... Ułożyć na tej karteczce....!,

- kierowali własnym działaniem i głośno „mówili do siebie”35: To zróbmy sobie jeszcze tym sposobem... Jak przełożymy jedno jabłko tu... ... więc jak przełożysz dwa albo trzy, albo pięć, albo sześć... Teraz jak przełożę...,

${ }^{35}$ L.W. Wygotski nazywa głośne mówienie mówieniem do siebie; to monitorowanie, kierowanie własnym działaniem. 
- szukali kontaktu wzrokowego i potwierdzenia w formie werbalnej lub niewerbalnej, że „mały uczeń" rozumie sens eksperymentowania.

Działaniem finalizującym ciąg czynności intelektualnych, które wytyczały kierunek myślenia „małego nauczyciela” i stanowiły rozumny tok postępowania w rozwiązywaniu zadania matematycznego, była końcowa refleksja, czyli wnioskowanie. „Mali nauczyciele" robili to w następujący sposób:

- wskazywali na przedmioty, które obrazowały wynik eksperymentowania i stwierdzali: Widzisz, wystarczy tylko poprzekładać... Ułożyć na tej karteczce $i$ wtedy tylko wystarczy poprzekładać $i$ wyjdzie ci wynik. I na koniec, musimy policzyć, aby dojść do wyniku. Czyli musisz zmierzyć,

- skłaniali do refleksji, czy wynik eksperymentowania z przedmiotami spełnia warunki podane w zadaniu i stawiali pytania: Załóżmy, że tu masz motocykl. Więc gdzie go stawiasz? To ile jabłek przełożyłaś? Czy mamy po tyle samo?,

- dawali do zrozumienia, że można wybrać wynik eksperymentowania i wskazywali różne możliwości rozwiązania manipulacyjnego: Tak tė̇ chyba może być. Może być, albo tak, albo tak.

Decyzje podejmowane przez „małego nauczyciela” miały charakter łańcuchowy. Był to splot dwóch wzajemnie przeplatających się procesów: procesu myślowego - wewnętrznego, tzw. czarnej skrzynki, czyli tego, co się działo w środku, i działań zewnętrznych, tj. wykonywania eksperymentów. Podobieństwo przekształceń zastosowanych przez wszystkich „małych nauczycieli” jest jakby wiązką sposobów, różniących się między sobą łańcuchów czynności, ale opierających się na tych samych zasadach i prawidłowościach i stanowi strategię preferowaną przez małych nauczycieli.

Strategię tę przedstawiam na schemacie graficznym (rys. 1). Trzy prostokąty ukazują cały proces rozwiązywania zadania, czyli kolejne ciągi czynności realizowane od momentu zapoznania się z treścią zadania, po jego rozwiązanie.

Pierwszy prostokąt od lewej ilustruje pierwszą regułę - pierwsze przekształcenia, których dokonuje każdy „mały nauczyciel”, a więc przekształca sytuację zadaniową przedstawioną słownie w rodzaj problemowego wydarzenia matematycznego. „Mali nauczyciele” po przedstawieniu całości zadania lub jego fragmentu od razu przechodzili do przekształcenia sytuacji wyjściowej i zastępowali dane dotyczące liczby i miary konkretnymi przedmiotami. Przekształcenie jest bardzo ważne, ponieważ już tutaj większość „małych nauczycieli” komunikuje o celu, sposobie i planie działania: przypomina pytanie końcowe i za pomocą słów i gestów zaznacza to, co jest dane i szukane.

Drugi prostokąt ilustruje drugą regułę - drugie przekształcenia, czyli eksperymentowanie i obserwowanie zmian. „Mały nauczyciel” eksperymentował, czyli manipulował przedmiotami o charakterze kombinatorycznym, badał zależności pomiędzy danymi i szukanymi, obserwował sytuację i wyciągał wnioski. W tym momencie procesu rozwiązywania zadania szczególnie widoczny jest dynamizm strategii stosowanej przez „małego nauczyciela”. Eksperymentując przedmiotami, uczniowie badali 
związki pomiędzy informacjami zawartymi w treści zadania oraz odkrywali poprzez ciąg czynności zewnętrznych i myślowych różne warianty kombinacji.

Trzeci prostokąt ilustruje trzecią regułę - ostatnie przekształcenia, moment wyciągnięcia wniosków i podjęcia decyzji, że zadanie zostało rozwiązane.

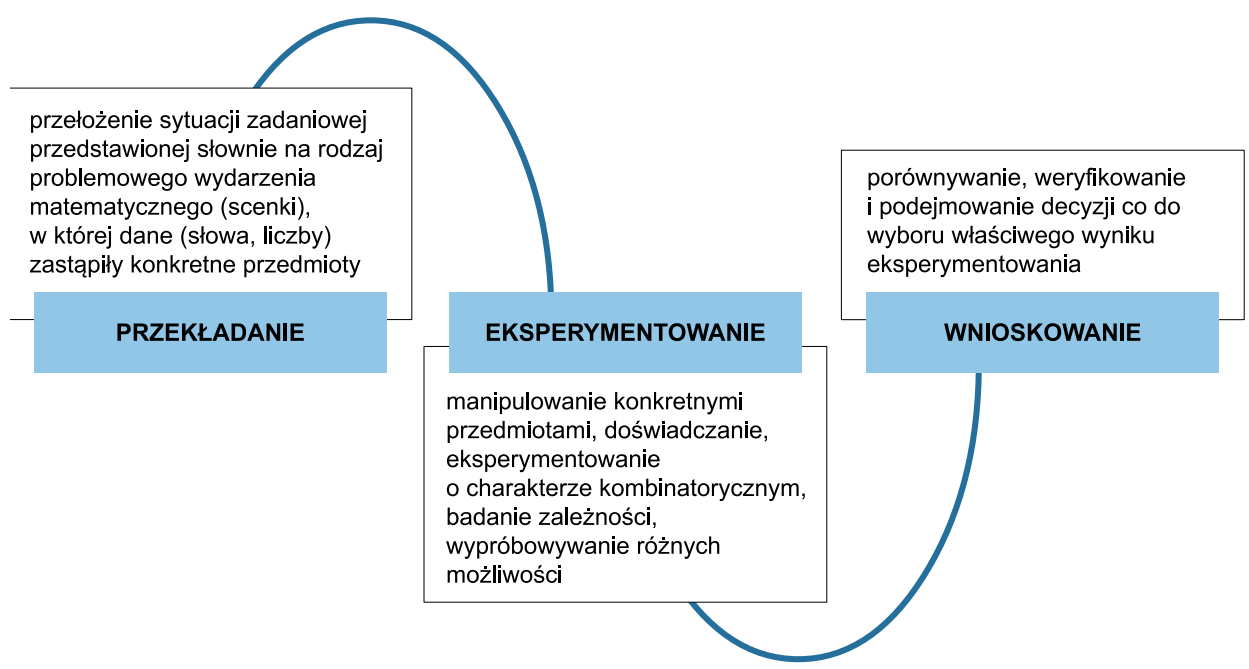

Rysunek 1. Strategia preferowana przez „małych nauczycieli” w trakcie uczenia „małych uczniów" rozwiązywania zadań matematycznych z treścią

Źródło: opracowanie własne.

\section{Podsumowanie}

Sytuacja, w której znalazł się uczeń klasy trzeciej, była sytuacją problemową, gdyż była to sytuacja nowa, nieznana, trudna ${ }^{36}$. Zwykle na lekcjach matematyki uczeń uczy się i rozwiązuje zadania, a nie uczy innych, jak rozwiązywać zadanie. Polecenie, które otrzymał od badającego, różniło się od poleceń, które można przeczytać w pakietach edukacyjnych i brzmiało: Pomóż młodszemu koledze (koleżance) rozwiązać zadanie. Żeby sprostać temu zadaniu, uczeń klasy trzeciej, pełniący w badaniu rolę „małego nauczyciela”, musiał samodzielnie wybrać drogę pokonania trudności i przyjąć właściwą strategię ${ }^{37}$.

36 J. Kozielecki, Rozwiązywanie problemów..., dz. cyt., s. 14-15.

$37 \mathrm{~W}$ edukacji matematycznej stosuje się szereg pojęć opisujących czynności ucznia podejmowane w toku rozwiązywania zadania. Są to: sposób, metoda, strategia. Przyjęłam za J. Kozieleckim, że strategia jest pojęciem ogólniejszym, bardziej syntetycznym niż sposób i jest ona jakby wiązką sposobów różnych łańcuchów czynności, powiązanych ze sobą regułami. Strategię myślenia, czyli czynności (operacje) myślowe można badać, obserwując to, jakie czynności uczeń wybiera i jakie są to prawidłowości, reguły ich wyboru. Zob. J. Kozielecki, Strategia psychologiczna. Psychologiczna strategia rozwiązywania problemów, Nasza Księgarnia, Warszawa 1975, s. 25-32. 
Zastosowana w badaniach procedura ${ }^{38}$ w sytuacji dialogowej dała możliwość swobodnego porozumiewania się uczniów między sobą i „odkrycia rzeczy niewidzialnych", czyli sposobu ich rozumowania w trakcie rozwiązywania matematycznych zadań z treścią.

Bezspornie konieczna jest rewizja metod rozwiązywania zadań matematycznych zalecanych w nauczaniu początkowym, gdyż przedstawiony $\mathrm{w}$ tym artykule fragment badań $i$ ich interpretacja pokazują, że uczeń, kiedy nie musi poddawać się prowadzeniu dorosłego, samodzielnie odkrywa drogi pokonania trudności, eksperymentuje i wyciąga z tych doświadczeń wnioski. Ponadto wszystkie przekształcenia dokonywane przez „małych nauczycieli” były ich osobistym wyborem i stanowily jakby kanon reguł, na których opierały się kolejne ich czynności. Podobieństwo tych przekształceń (transformacji) zastosowanych przez wszystkich uczniów klas trzecich stanowi strategię intelektualną, która jest jakby wiązką sposobów, splecioną z różnych łańcuchów czynności, ale opierających się na tych samych regułach i prawidłowościach. Przekształcenia (transformacje) mogą być dokonywane nagle ${ }^{39}$ lub po zastanowieniu, ale każde z nich jest krokiem naprzód w rozwiązywaniu zadań.

Potwierdzeniem potrzeby podjęcia pogłębionej refleksji nad sposobem rozumowania uczniów klas trzecich są przeprowadzone cyklicznie badania krajowe ${ }^{40}$. Pokazują one, że na lekcjach matematyki dominują nadal ćwiczenia stosowania algorytmów, a nie tworzenie warunków do budowania przez dzieci różnych sposobów postępowania: liczenia, zastosowania posiadanych wiadomości podczas rozwiązywania zadań i problemów.

\section{Bibliografia}

Bauman Z., Wyzwania dla edukacji w dobie płynnej nowoczesności, [w:] R. Siemieńska (red.), Uniwersytety, naukowcy i studenci w zglobalizowanym świecie: wybrane zagadnienia, Wydawnictwo Naukowe Scholar, Warszawa 2017.

Dąbrowski M., (Za) trudne, bo trzeba myśleć?, Instytut Badań Edukacyjnych, Warszawa 2013.

Dąbrowski M., O umiejętnościach matematycznych trzecioklasistów - subiektywny wybór z badań, „Studia Pedagogiczne” 2015, nr LXVII.

${ }^{38}$ Sposób dotarcia do tego, jak myśli trzecioklasista, oparty został na regułach komunikowania się społecznego Z.I. Kałmykowej i teorii strefy najbliższego rozwoju L.S. Wygotskiego, stosowanej też przez E. Gruszczyk-Kolczyńską.

${ }^{39}$ Przekształcenie sytuacji problemowej odbywa się nagle, kiedy to rozwiązujący problem doznaje olśnienia. Zob. M. Wertheiner, Productive Thinking, Harper and Row, New York 1945.

${ }^{40}$ Zob. M. Zambrowska, M. Karpiński, B. Kondratek, Kompetencje matematyczne trzecioklasistów, Instytut Badań Edukacyjnych, Warszawa 2015, s. 10-24. 
Dąbrowski M., Pozwólmy dzieciom myśleć, Centralna Komisja Egzaminacyjna, Warszawa 2008.

Dąbrowski M., Wiatrak E., Podsumowanie badania umiejętności matematycznych, [w:] A. Pregler, E. Wiatrak (red.), Ogólnopolskie Badanie Umiejętności Trzecioklasistów. Raport OBUT 2012, 2013 i kolejne, Centralna Komisja Egzaminacyjna, Warszawa.

Dewey J., Jak myślimy?, Książka i Wiedza, Toruń 1957.

Gruszczyk-Kolczyńska E., Dzieci ze specyficznymi trudnościami w uczeniu się matematyki. Przyczyny, diagnoza, zajęcia korekcyjno-wyrównawcze, WSiP, Warszawa 1992.

Gruszczyk-Kolczyńska E. (red.), Wiadomości i umiejętności oraz zarysowujące się uzdolnienia matematyczne starszych przedszkolaków i małych uczniów. Podręcznik, narzędzia diagnostyczne oraz wskazówki do wspomagania rozwoju umysłowego i edukacji uzdolnionych dzieci, Akademia Pedagogiki Specjalnej w Warszawie, Warszawa 2010.

Gruszczyk-Kolczyńska E., Dojrzałość emocjonalna i jej znaczenie w uczeniu się matematyki, [w:] E. Gruszczyk-Kolczyńska, Dzieci ze specyficznymi trudnościami w uczeniu się matematyki. Przyczyny, diagnoza, zajęcia korekcyjno-wyrównawcze, WSiP, Warszawa 1992.

Gruszczyk-Kolczyńska E., Układanie i rozwiązywanie nieco bardziej złożonych zadań z treścią, [w:] E. Gruszczyk-Kolczyńska (red.), Edukacja matematyczna w klasie I. Książka dla rodziców i nauczycieli, Wydawnictwo CEBP, Kraków 2014.

Gruszczyk-Kolczyńska E., Wspomaganie rozwoju umysłowego oraz edukacja matematyczna dzieci w ostatnim roku wychowania przedszkolnego i w pierwszym roku szkolnej edukacji, Edukacja Polska, Warszawa 2009.

Gruszczyk-Kolczyńska E., Zielińska E., Dziecięca matematyka dwadzieścia lat później. Książka dla rodziców i nauczycieli starszych przedszkolaków, Bliżej Przedszkola, Kraków 2015.

Jeleńska L., Kształcenie myślenia matematycznego, [w:] L. Jeleńska, A.M. Rusiecki, Metodyka arytmetyki i geometrii w pierwszych latach nauczania, Państwowe Zakłady Wydawnictw Szkolnych, Warszawa 1958.

Kalinowska A., Nauczyciele o edukacji matematycznej, [w:] M. Dąbrowski (red.), Badanie umiejętności podstawowych uczniów trzecich klas szkoły podstawowej. Trzecioklasista i jego nauczyciel, Centralna Komisja Egzaminacyjna, Warszawa 2009.

Kalinowska A., Pozwólmy dzieciom działać. Mity i fakty w kształceniu myślenia matematycznego, [w:] M. Dąbrowski (red.), Badanie umiejętności podstawowych uczniów trzecich klas szkoły podstawowej. Trzecioklasista i jego nauczyciel, Centralna Komisja Egzaminacyjna, Warszawa 2009.

Kalinowska A., Umiejętności matematyczne uczniów kończących klasę trzecią. Czytanie tekstów matematycznych, [w:] M. Dąbrowski (red.), Trzecioklasiści 2010. Raport z badań ilościowych, Centralna Komisja Egzaminacyjna, Warszawa 2011. 
Kałmykowa Z.I. (red.), Ostajuszczije w uczenii szkolniki. Problema psychiczeskowo rozwitija, Moskwa 1986.

Kałmykowa Z.I., Problemowo-syntetyczna metodyka diagnostyki nauczalności, [w:] L. Wołoszynowa (red.), Materiały do nauczania psychologii, seria 3, t. 2, PWN, Warszawa 1973.

Klus-Stańska D., Mentalne zniewolenie nauczycieli wczesnej edukacji - epizod czy prawidłowość, „Problemy Wczesnej Edukacji” 2005, nr 1(1).

Klus-Stańska D., Nowicka M., Sensy i bezsensy edukacji wczesnoszkolnej, Harmonia Universalis, Gdańsk 2014.

Kocur M., Arystotelesowskie poglądy konstytutywną częścią filozofii i pedagogiki, [w:] A. Murzyn (red.), Paideia starożytnej Grecji i Rzymu, Oficyna Wydawnicza „Impuls”, Kraków 2011.

Kozielecki J., Rozwiązywanie problemów, Państwowe Zakłady Wydawnictw Szkolnych, Warszawa 1969.

Kozielecki J., Strategia psychologiczna. Psychologiczna strategia rozwiązywania problemów, Nasza Księgarnia, Warszawa 1975.

Krygowska Z., Zarys dydaktyki matematyki. Cz. 3, WSiP, Warszawa 1980.

Piaget J., Mowa i myślenie dziecka, PWN, Warszawa 1992.

Piaget J., Studia z psychologii dziecka, PWN, Warszawa 1966.

Polya G., Odkrycie matematyczne. O rozumieniu, uczeniu się i nauczania rozwiązywania zadań, cz. 1 i 2, Wydawnictwa Naukowo-Techniczne, Warszawa 1975.

Pregler A., Wiatrak E. (red.), Ogólnopolskie Badanie Umiejętności Trzecioklasistów. Raport OBUT 2012, 2013 i kolejne, Centralna Komisja Egzaminacyjna, Warszawa.

Puchalska E., Semadeni Z., Nowe spojrzenie na zadanie tekstowe, [w:] Z. Semadeni, J. Bargoń (red.), Nauczanie początkowe matematyki. Tom 1, WSiP, Warszawa 1981.

Rozporządzenie Ministra Edukacji Narodowej z dnia 14 lutego 2017 r. w sprawie podstawy programowej wychowania przedszkolnego oraz podstawy programowej kształcenia ogólnego dla szkoły podstawowej, w tym dla uczniów z niepełnosprawnością intelektualną w stopniu umiarkowanym lub znacznym, kształcenia ogólnego dla branżowej szkoły I stopnia, kształcenia ogólnego dla szkoły specjalnej przysposabiającej do pracy oraz kształcenia ogólnego dla szkoły policealnej, Dz.U. 2017, poz. 356.

Schaffer H.R., Psychologia dziecka, PWN, Warszawa 2005.

Semadeni Z., Gruszczyk-Kolczyńska E., Treliński G., Bugajska-Jaszczołt B., Czajkowska M. (red.), Matematyczna edukacja wczesnoszkolna. Teoria i praktyka, Wydawnictwo Pedagogiczne ZNP, Kielce 2015.

Szuman S., Rola działania w rozwoju umysłowym małego dziecka, Wydawnictwo Polskiej Akademii Nauk, Wrocław 1955.

Sławińska M., Tutoring rówieśniczy w edukacji, czyli jak uczniowie ucza się od siebie wzajemnie i co z tego wynika, „Forum Oświatowe” 2015, nr 27(2). 
Sobol E. (red.), Ilustrowany słownik języka polskiego, PWN, Warszawa 1999.

Tyszkowa M., Zachowanie się dzieci 5-12 letnich w trudnych sytuacjach zadaniowych, [w:] J. Obuchowska, O.W. Owczynnikowa, J. Reykowski (red.), Badania nad osobowością dzieci i młodzieży, WSiP, Warszawa 1979.

Wertheiner M., Productive Thinking, Harper and Row, New York 1945.

Włodarski Z., Rozwój i kształtowanie doświadczenia indywidualnego, PWN, Warszawa 1975.

Wiszniakowa-Zielenskiy N., Koncepcje rozwoju kreatywnego potencjału człowieka, Oficyna Wydawnicza AFM, Kraków 2016.

Wygotski L.S., Narzędzie i znak w rozwoju dziecka, Wydawnictwo Naukowe PWN, Warszawa 2006.

Zambrowska M., Karpiński M., Kondratek B., Kompetencje matematyczne trzecioklasistów, Instytut Badań Edukacyjnych, Warszawa 2015.

\section{Strategies favored by small teachers in the field of learning content tasks to small students. Research report}

Abstract: A characteristic feature of learning mathematics is solving specially selected tasks. While arranging and solving problems, children accumulate mathematical and logical experiences. From these experiences, their mind constructs mathematical competences. Content tasks play a special role in this process, because in the course of solving them, students not only gain experience, but also learn to apply their knowledge and skills in life situations.

Therefore, a key issue for the purposes of mathematics education is examining the ways of reasoning of younger school-age children when solving math problems. In this article, I discuss the strategies preferred by third-grade students when teaching younger students to solve math problems with content. I also present fragments of a detailed empirical analysis of the verbal and non-verbal behavior of students working in pairs to solve specially selected tasks.

Keywords: the process of learning children at a younger school age, solving mathematical tasks, peer tutoring

\section{About the Author:}

Joanna Zalewska - MA in Pedagogy, specializing in early childhood education, employee of Akademia Pedagogiki Specjalnej im. Marii Grzegorzewskiej (the Maria Grzegorzewska Academy for Special Education) in Warsaw. Qualified Teacher with years of experience in pedagogy. Areas of interest: mathematical education, the nature of children's thinking, innovative teaching methods. 